\title{
Literary Voices of Luanda and Maputo: A Struggle for the City
}

\author{
MARGARIDA CALAFATE RIBEIRO \\ Universidade de Coimbra \\ University of Bologna
}

\begin{abstract}
In this article, I provide an overview of literary portrayals of the cities of Luanda and Maputo over the course of their histories from the colonial period to the post-independence era. In particular, I draw on the literary images and descriptions of the cities to demonstrate a design of inequality that their urbanism determines. Finally, I argue that a struggle for terrain and citizenship-in the conquest of space by colonizers and the reconquest of lost places by the colonized-draws the lines of that inequality.
\end{abstract}

Keywords: Angola; Mozambique; Colonial and postcolonial literature; Urban studies

African literatures, particularly those expressed in the languages of the former colonizers, arose to expose and denounce the inequality underpinning the colonial system. ${ }^{1}$ Through these literatures, a language of oppression and colonialism transformed into a language of emancipation, writing the cultural difference that would engender the political independence of nations. In this article, I will draw on the literary images and descriptions of the cities of Luanda and Maputo to demonstrate a design of inequality that their urbanism determines.

\footnotetext{
${ }^{1}$ This article results from the project "De S. Paulo de Luanda a Luuanda, de Lourenço Marques a Maputo: capitais coloniais em tempos pós-coloniais" (PTDC/CLELLI/122229/2010 - FCOMP-01- 0124-FEDER- 019830), which was financed by Fundos FEDER through the Programa Operacional Factores de Competitividade and by the Fundação para a Ciência e a Tecnologia.
} 
A struggle for terrain and citizenship - in the conquest of space by colonizers and the reconquest of lost places by the colonized-draws the lines of that inequality.

The authors of the emerging national literatures of Portuguese-speaking Africa, particularly in Angola and Mozambique, generally grew up in the colonial capitals. The precursor literatures of liberation they produced were thus essentially a phenomenon of urbanism (Trigo). They were concerned with city life and with fostering an urban culture centered on newspapers, clubs, and social activities. The polis was the stage they chose to expose inequality. They portrayed it first hand, by drawing on their observations of the functioning and planning of the cities of their youth.

Given the historical and geographical context in which these authors wrote, the concept of literary formation rather than foundational literature seems a more appropriate tool on which to draw to read their work, born of a self-interrogating colonial heritage fused with African roots. Expounded by Antonio Candido in relation to Brazilian literature, with a variant offered by Mário António referencing Angolan literature, it can be simply put: "formation is something which is formed." "Why do I prefer the concept of "formation" over the more classical vision of foundational literatures closely associated with the emergence of nationhood in nineteenth-century Latin America? It comes down to colonial and postcolonial connotations. Foundation, a term applied in reference to cities and cultures in previously colonized spaces was thus a colonial act that disciplined literature and cities into binary hierarchies: there was colonial literature and the Other's literature, the colonial city and the Other's space. The use of the term "foundational," as Antonio Candido points out, perpetuates a narrative that implies that, prior to the arrival of Europeans, there was nothing there. It creates the impression of a ground zero in which history started at a foundational moment.

Published in 1989, "Vilas et Cidades": Bourgs et villes en Afrique lusophone, edited by Michel Cahen, was the first study of urban space in Portuguese-speaking Africa. At the time, the issue of the foundation of cities as such was not the object of much analysis. There was a greater emphasis on description. Recently Cidades e Império: dinâmicas coloniais e reconfigurações

\footnotetext{
${ }^{2}$ The classic definition of formation as "history of Brazilians in their desire to have a literature" fits the idea of a literature that is formed (Candido 25).
} 
pós-coloniais, edited by Nuno Domingos and Elsa Peralta, shows how research of an essentially ethnocentric hue has been conducted in colonized spaces since the arrival of Europeans (xii). Certainly, there were not cities in the Western sense of the word. As Walter Rossa affirms, the city is "uma criação da civilização ocidental, e pelo menos no Ocidente, a civilização continua a ser impensável sem elas e sem as redes que elas formam" (78). In these parts of Africa, there was a different ordering of spaces, where people lived together in communities, as can be seen on early maps and in early descriptions of colonization, an ordering that underwent tremendous change as Europeans began their processes of conquest. ${ }^{3}$ Rossa asserts "inevitavelmente as cidades foram um dos principais instrumentos usados pelos europeus no estabelecimento dos seus sistemas coloniais, começando logo com os primeiros, o português e o espanhol, no início da primeira modernidade" (78). Consequently, studies produced about African cities are overwhelmingly part of a grand European narrative defining these locations. By analyzing the voices of African literatures about Luanda and Maputo, I aim to show the other side of a seemingly common history, one with very different memories.

\section{The colonial era}

The imposition of cities in the European sense on colonized spaces introduced a dynamic of a struggle for territory, which gained weight and took various forms. One domain in which the struggle became obvious was literature that described urban life. From within the variegated contours of the cities, local elites and cultures emerged, which in the case of Luanda became apparent from 1576, passing through various historical stages, and in Lourenço Marques took shape at the end of the nineteenth century. Initially, the portrayal of the city was steeped in the political affirmation of colonial power, as early descriptions highlighted strategic places and architectural marvels so that readers could grasp what they looked like, judge their importance and understand their nature as capitals. Like every Portuguese colonial capital, and the metropolis itself, Luanda and Maputo are on the coast, with the result that the maritime districts played a fundamental

\footnotetext{
${ }^{3}$ See Henriques and Vieira. Domingos and Peralta provide an extensive list of studies on pre-colonial space in Africa. See xiii, n2.
} 
role in city life and were correspondingly prevalent in literature. They rivaled Lisbon with monuments on their skylines and buildings that affirmed powertheir port, forts, squares, churches and administrative offices, filled with elites and colonial bureaucrats who exercised that power either locally or through their connections with Lisbon.

António Oliveira Cadornega describes the strategic impressiveness of the city that functions as a center of commercial and military power, and with which he identifies as both a resident of São Paulo de Assunção de Luanda and a native of Vila Viçosa, Portugal. His História includes poems, among which are unattributed verses that allow Cardonega to broach from an urban perspective the city's insularity, its streets, its colors, its speech, and its people, linked to slaves and every type of legal and not-so-legal trade. That trade gave Luanda an architecture echoed in Salvador da Baía, since both cities operated in similar ways for the centuries of the slave trade. Both were also colonial capitals on the South Atlantic, exporting raw materials and agricultural products. They were centers of cultural, financial, and social circulation, bound up with trade, as shown in Luís Félix da Cruz's, "Descrição da cidade de Loanda e reyno de Angola":

Nesta turbulenta terra

almazem de pena e dor, confuza mais de temor.

Inferno em vida.

Terra de gente oprimida, Monturo de Portugal, por onde purga seu mal, e sua escoria

Onde se tem por vãa gloria, a mentira e falsidade, o roubo, a malinidade, o interesse

Donde a justiça perece 
por falta de quem a entenda, donde para haver emenda, uza Deos

do que uzava com os Judeos, quando era Deos de vingança, que com todas as três lanças de sua ira. (Marques and Ferreira 466) ${ }^{4}$

In the modern colonial era, an era in which Maputo came to imperial prominence and which changed the feel of Luanda, the colonial city was characterized by cement and tarmac, where whites were concentrated and power structures solidified. Further out, on the peripheries, there was the "other" city, constituted by an amalgam of mixed races, blacks and poor whites who lived in Luanda's musseques and Maputo's caniços. As a result of this social apartheid, the colonial city became a spatial expression of the inequality instated by the colonial order, but also a locus of opportunities. It gave access to work, education, and culture. It provided living conditions of sorts. In effect, this urbanism of inequality transformed the city's peripheries, where people from throughout the colonial territory lived, into the cultural backdrop for a new political awareness and the cradle of a literature of nationhood.

The cities of Luanda and Maputo are interrelated by the long Portuguese colonial presence that, in unequal conviviality with other influences, progressively defined the cities as a textual polyphony (Canevacci). However, very diverse geographies (Luanda on the South Atlantic and Maputo facing the Indian Ocean), different temporalities, and distinct historical pasts separate them, reflected in the literature representing and presenting the cities. While a large part of Angolan literary imagery centered on the city of Luanda, since its inception textually represented and from the 1950s abundantly portrayed, the same cannot be said of Maputo, which never occupied a central place in Mozambican literature to the same extent. From the perspective of the imagery of centrality and power, Portuguese colonial and Mozambican literature celebrate the Ilha de Moçambique far more than Lourenço Marques (as Maputo was formerly known).

\footnotetext{
${ }^{4}$ Topa proves Cruz's authorship of this poem initially published by Cadornega.
} 
In fact, Maputo is a relatively recent administrative and political capital. Its colonial writers had very little time to describe their city-as-capital. The Other's city, on the capital's periphery in districts like Mafalala, and neighborhoods like Chamanculo and Xipamanine, became the fundamental references of colonial subalternity abundantly portrayed in Mozambican literature. José Craveirinha and Noémia de Sousa were early poetic giants to emerge from and celebrate these peripheral districts. Later, Calane da Silva, Luís Carlos Patraquim, and Nelson Saúte contributed to the establishment of Mafalala as a byword for poetry, the struggle against colonialism and a freed nation.

The history of Luanda and Maputo, recorded in the various forms of literature arising from their midst, is the history of a struggle for territory, whether from a perspective of conquest and appropriation in Portuguese colonial literature, or with the recovery of that territory in sight, in Angolan and Mozambican literatures from the 1940s and 1950s onwards. Poetry marks the territory, emphasizing it, and conjuring images of people who parade under our gaze as if they were in a photo album. Narratives describe the cities as places in motion through their denizens, with their customs, their work, their houses, their talk, their cosmogonies, and their stories.

Any analysis of the city implies various forms of recording, appropriation, and description. The two cities under analysis share a common feature: they were designed and very often described by those who did not live in them but merely imagined them as aspects of a formal city, particularly a colonial city. Yet they were effectively formed by those who gave them life and resided in them. This group often came from outside the urban boundaries, as was the case of those from mainland Portugal (the metropolitanos) in the colonial era, portrayed in Portuguese colonial literature, or the case of migrants from the hinterland, attracted by the development inherent to a capital, in a common movement from the countryside to the town both before and after independence. The majority of the latter were the men and women who lived in the musseques of Luanda and caniço of Maputo. They embody and shape Angolan and Mozambican literatures. Their numerous literary expressions of belonging and conquest of the territory interplay with the concept of foundation and formation. Through that interplay, the city unveils its ethnic, social, and political multiplicity, delineating the various layers of inequality generated within its terrain in the very place that, in principle, should welcome and foster the equality of those who live in it. 
The literature of the 1940s and 1950s can be categorized into at least two sets: colonial literature and local literature. Local literature, produced by those who lived in the cities, gave birth to the national literatures of Mozambique and Angola. Local literature affirmed feelings generated around urban models, flourishing among a mixed race elite in the early twentieth century, gaining momentum especially through newspapers and the first cultural and sports associations. It was marked by an experience of the colonial-oriented and segregated city. In a different form, but with the same content, in the postindependence era, city models were also discussed by focusing either on the alienation of a city occupied by those who had never lived there before, or by talking of a city bursting at its seams that did not welcome those in search of a better life or fleeing lengthy civil wars.

In 1943, Júlio de Castro Lopo wrote at the beginning of his book Alguns aspectos dos musseques:

Os europeus que vivem na cidade-baixa e na cidade-alta-nos lugares enfim civilizados de Luanda-estão longe de fazer ideia exata do que sejam os musseques, os lendários arredores da capital de Angola.... Todos estes musseques (além dos não citados) constituem subúrbios da capital de Angola: a sul, leste e nordeste da cidade, ou seja: desde o bairro da Maianga (parte alta) até Sambizanga. (5)

It is not difficult to find an equivalent observation about the city of Lourenço Marques/ Maputo. Literary texts, more than any other genre, present us with the subtle differentiations inherent in the histories of both cities highlighted by Castro Lopo. He outlines various ideas. First, and most obviously, there is a line dividing the city, and beyond that line, the city is totally unknown to the colonial population. Second, the reverse is not the case, because blacks and mixed-race people worked in the heart of the colonial city, coming to know the habits, culture, and language of those who lived there. Third, the line divides the populations not only according to their economic conditions, but also by race. And finally, the geography of the musseques announces other forms of struggle for the territory that will take place. The musseque encircles the white, colonial city. From the 1940s onward, it is the place of enunciation for struggle and for Angolan and Mozambican literatures. 
Clear lines thus divide the colonial city, essentially white, from the rest, whose cartographic portrayal ranges from pure non-representationemptiness - to lines marking the beginning of the indigenous neighborhoods, in the colonial formulation. In the middle are transition neighborhoods, normally with indigenous names or linked to the profession of their residents-Alto Maé or Chamanculo in Maputo, and Bairro Operário in Luanda-usually inhabited by poorer whites and low-ranked administration employees and traders.

Colonial literature replicates the erasure or ignorance of anything beyond the white city. According to Francisco Noa, from the 1930s onwards, due to the policy of the Estado Novo, colonial literature began to take on a decidedly ideological tone. By the late 1950s and early 1960s, it became aesthetically more sophisticated and cosmopolitan, coinciding with the city's replication of districts similar to those found in Lisbon like Alvalade and Benfica. It even copied their names, as well as major social infrastructures such as schools and leisure facilities. At different stages, colonial literature reaffirmed the conquest and urban acculturation of the territory, with plots that took place in the white city, with white characters, cloaking in invisibility the largest part of the city's space and population. Hipólito Raposo, António Pires, Maria Archer, Henrique Galvão, and Maria da Graça Azambuja among many others wrote about Angola in this way. Brito Camacho, Julião Quintinha, Guilhermina Azeredo, Manuel Rodrigues Júnior, and Eduardo Paixão did the same about Mozambique. In their midst, there are works revealing the ambiguity of the colonial situation by showing the frontier spaces in which many people moved. These narratives of colonialism contain a version of history that numerous individuals would later invoke to justify their relationship of belonging to that colonized land. Distancing themselves politically from their context, a series of voices stand on both sides of the fence, recalling the old city through the metaphor of a childhood in which white, black, and mixed-raced children played together peacefully, against the modernization ushered in by progress, but also segregation as mixed-raced elites were pushed to the city's peripheries. Examples of this appear in the poetic voices of the magazine Cultura, in the autobiography Era o Tempo das Acácias by Carlos Ervedosa, or in poems by Mário António, Cochat Osório, Tomás Vieira da Cruz, and António Jacinto. Jacinto's “O Grande Desafio," talks of children of all races playing in the street until adult restrictions meant that games had to be played in different ways. 
The Angolans António Jacinto, Viriato da Cruz, and Agostinho Neto wrote poetry denouncing the colonial situation, portraying the musseque, with its workers, their poverty, their hunger, and their unschooled children. Yet it is also a place of alternative wisdoms, other orders, other ideas, other languages and cultures. Later, prose by Boaventura Cardoso, Jofre Rocha, António Cardoso, and José Luandino Veira asserted the musseque as a political space by converting it into a metaphor for the shackled and struggling nation and so, literarily speaking, this is the place of enunciation of pre-independence Angolan literature, indelibly shaping practically all its novels and many poems.

In Mozambique, Rui Noronha and Orlando Mendes configured the divided city by contrasting the cement city with the reed city. As in Angola, the borderline sites were spaces privileged by literature in order to illustrate the porosity of those divisions, a situation that persists to this day, as portrayed by Hélder Faife in his 2010 novel, Contos de fuga: "Dobrei a esquina que fronteira os bairros. Não cai, habituado ao súbito contraste do chão que carateriza o litoral urbano. Ali, o casal pavimento e asfalto divorcia-se bruscamente e deixa a amante, a areia, orientar os caminhos" (9).

As today, neither in Luanda nor in Maputo were the colonial city and its peripheries homogenous. Within these two stark divisions marking the inequality that characterized colonialism, reflected in the design of the city, a series of other inequalities scar the landscape, divided by professional, ethnic, and economic conditions that define the social status of each neighborhood and its inhabitants. ${ }^{5}$ Colonial society was itself stratified, like the suburbs, with a range of divisions based on religion, ethnicity, origin, as well as cultural differences. There were assimilados, mestizos, blacks, Muslims, Christians, political leaders, poets, and musicians. In fact, in the city of Lourenço Marques, it was just as unlikely that an Indian, Chinese, or white, low-income worker, and resident of Maxaquene or Alto Maé, with their dirt tracks, poor lighting, and humble houses, would cross paths with someone from Polana as with an inhabitant of Mafalala or Xipamanine. However, these frontier spaces were fundamental in the struggle for independence to develop with their characters in transit between one place and

\footnotetext{
${ }^{5}$ In "Ronda dos leques ou terapêutica da ocupação laurentina a partir do litoral," the poet Grabato Dias offers a description of the socioeconomic status of the residents of the city of Lourenço Marques based on car brands and the women associated to spaces of the city (48-49).
} 
the other. This is not merely a physical transit to go to a club or to visit prostitutes, but also a cultural and political transit and communion towards an awareness of subalternity, inequality, and injustice.

While these frontier spaces are of crucial importance, the reed neighborhoods of Xipamanine and Mafalala are most significant as culturally affirmed metaphors of the shackled and struggling nation through the voices of their great poets. The workplaces, the deportations to São Tomé in the dead of night in the silent city, the port, the caniço and its appalling conditions, its hungry and unschooled children, the cosmopolitan movement of its bars, clubs, and sports associations are spaces of affirmation and conviviality gathering various social layers around cinema, jazz, cabarets, and prostitution. The places enjoined poets to denounce injustice and proclaim the struggle. Noémia de Sousa and José Craveirinha are the first to set the tone in their poems. Sousa was particularly attentive to doubled female subalternity in verses such as "Cais," and "Moças das Docas." Craveirinha's extensive work included poems dealing with urban divisions such as, "Nossa Cidade," "Afinal a bala do homem mau," and "Mamanô."

As in Angola, inequality was not just defined by evoking poverty, exploitation and inadequate conditions, but also by the affirmation of cultural differences, unknown to the white city or otherwise considered savage. Craveirinha epitomizes that difference in his poem,"Quero ser tambor," through images of drums and the black city's dances, a noise the colonial city would rather not hear. Rui Knopfli is an example of a poet who came from Polana, one of the most elegant zones of Lourenço Marques. Even so, he became involved in the active denunciation of the colonial situation in Mozambique, capturing the anesthetic climate of the cement city in "Winds of Change":

Ninguém se apercebe de nada ...

como é boa e mansa a Polana

nas suas ruas, túneis de frescura

atapetados de veludo vermelho

Tudo joga tão certo, tudo está tão bem

como num filme tecnicolorido

Passam. Passam

e tornam a passar 
Ninguém se apercebe de nada. (152)

Knopfli, like other poets from the colonial city, crossed the city's divisions and became one of the most visual poets from Lourenço Marques. Colonial Mozambique's capital remained in his memory when he went into exile after independence. While he lived in colonial Mozambique, he saw and voiced in the city the "invisibles," and the "transparent" - those laborers who worked in the white city and lived in the caniço, as in "Cantinela de Subúrbio":

\section{Do Jardim Vasco da Gama chega, para lá}

da sombra o percutir seco das bolas de ténis....

Do caniço, o soluço entrecortado da cantiga:

'Eu vou morrer na cantina com um copo de vinho na mão.

A cantina será cemitério

e o barril o meu caixão'....

Principia, lento, o agonizar dos dias. (37)

The sense of struggle heralding a confrontation to come embodied in the texts of that time, expressed the tension of different groups living in close proximity, characteristic of colonial society, and the colonial city in particular. It was not a linear opposition between whites and blacks or mixed race people, but between freedom and submission, social justice and inequality. These were the very same values that would underpin the struggle for independence, activating mechanisms of belonging and identity which, in a post-World-War-II context, were reflected in being Portuguese, Angolan, or Mozambican, while never neglecting class and racial differences. In Noémia de Sousa's "Godido," which echoes a character from João Dias's 1952 collection of short stories, Godido e outros contos, we hear of a black child wandering uncomfortably in the city's downtown, which does not belong to him and where he feels like a foreigner, searching for his own place in the world. The poem describes the violence of assimilation, a process based on sacrifice and the annulment of difference. At the same time, through formal education, racialized subjects became aware of the possibilities of critical 
thought. The very education they received as part of their assimilation in the colonial city led many blacks to rethink their position, as Sousa's poem contends:

Dos longes do meu sertão natal, eu desci à cidade da civilização.

Embriaguei-me de pasmo entre os astros suspensos dos postes das ruas

e atração das montras nuas

tomou-me a respiração

Todo esse brilho de névoa, ténue e superficial que envolve a capital, me cegou e fez de mim coisa sua.

Mas a cidade, a cidade, a cidade, a cidade!

Esmagou-me com os pneus do seu luxo, sem caridade, meus pés cortados nos trilhos duros do sertão,

Encarcerou-me numa neblina quase palpável de ódio e desprezo, e ignorando a luz verde do meu olhar, a maravilhosa oferta (essa estrela, esse tesouro) de cada minha mão aberta, exigiu-me impiedosamente a abdicação da minha qualidade intangível de ser humano!

Ah, mas eu não me deixei adormecer! Levantei-me e gritei contra a noite sem lua, sem batuque, sem nada que me falasse da minha África, da sua beleza majestosa e natural, sem uma única gota da sua magia! A luz verde incendiou-se no meu olhar e foi fogueira vermelha na noite fria dos revoltados. (130)

\section{After independence}


By the time the Liberation War began, Portuguese literature written from an experience of the Colonial War provided mainland Portuguese with impressions of the cities of Luanda and Lourenço Marques, in an approach perpetuating colonial literature to the extent that it merely looked at the cement city and the social and power relations inherent to it. In contrast, in the literatures of the Angolan and Mozambican armed struggles, the liberated site is not the city, but rather the bush - the sacred space of freedom fighters. In African novels and poems from that time, the capitals are symbolic places of colonial power and therefore the real and symbolic spaces of a territory to be won back (Ribeiro; Noa). Thus the capital city is converted into a symbol of conquest of the entire territory and independence. As such, it is also the space from and on top of which the new nation would be constructed, as signaled in Agostinho Neto's "Havemos de voltar."

After independence in 1975, various trends took root in the urban fabric, modifying the landscape, effectively constituting a different city with a different use of spaces, different symbols of power and different concepts of functionality. These changes were reflected in many novels and poems born of the new nation. A first stage imposed change on the city's toponyms, embodying a strong image of the end of colonialism by the re-appropriation of the city's territory, excluding some and including others in the public space. A number of colonial symbols disappeared, especially through the pulling down of emblematic statues, as Mia Couto captures in a text about the toppling of the equestrian statue of Joaquim Augusto Mouzinho de Albuquerque (161-63). Simultaneously, socialist-style statues began to appear, designating where power and sovereignty resided in the new capitals through the erasure of the symbols of the old order and the erection of a new order. Companies and services were nationalized, significantly transforming their presentation in the context of the city. Formal trade and the canteens decayed and, in their place, "peoples' shops" and duty free shops appeared, with a parallel growth in informal trade in huge open-air markets. There was an influx of suburban residents coming into the cement city replacing the massive departure of settlers, a process portrayed in novels such as Crónica da Rua 513.2 (2006), by João Paulo Borges Coelho, and A Canção de Zefanías Sforza (2010), by Luís Carlos Patraquim. Carlos Cardoso succinctly describes the process in "Primeiro Aniversário": "Hoje / aromas chamanculos / politizam os fogões / da polana" (57). 
Later, the Angolan civil war's encroachment on significant parts of the country and the subsequent arrival of displaced people from rural areas with an urgent need for accommodation in a city where their presence had never been countenanced offers the historical context for the plot of Manuel Rui's epic tale, Rio Seco (1997). The flow into the city of people from the hinterland who, replaying the colonial pairing civilized/uncivilized, saw in the city a space of progress and civilization, is a dynamic portrayed in the Mozambican Suleiman Cassamo's Palestra para um Morto (2004). The arrival of foreign aid workers from the most diverse parts of the former socialist block and their participation in the education and life of the city is portrayed in novels by a generation born after independence, including those of Ondjaki. Their presence was celebrated by the introduction of words in daily life relative to what these countries contributed to the Angolan and Mozambican urban space. For example, "Hungary," which appears in O Cronista, by Areosa Pena, refers to the buses Hungary donated to Mozambique as part of an aid and development package undertaken by the former Eastern bloc. In a similar vein, but involving postrevolutionary Portuguese assistance, the "Ramalho Eanes" in Quem me dera ser onda, by Manuel Rui, refers to the wine the former colonial power sent during an era of great economic and social upheaval, when there was a political rapprochement with Angola and Mozambique under Ramalho Eanes's presidency. In fact, the shortage of many basic items brought about changes in the urban population's habits and even vocabulary with words like "bichar" designating the long queues at the rationing shops, or the sarcastic "peixefritismo" which in Mozambique originally referred to the fish Agostinho Neto, the Angolan president, sent in ideological solidarity at a time the Mozambican population had next to nothing in their shops. Fried fish was one of the few foods available. The term transformed in daily and literary language into a metaphor, expressing a (utopian) commitment to an independent revolutionary Mozambique, resisting the onslaughts of global capitalism.

Post-independence fiction reflects the dawn of a new day, and is full of the great hopes of a new nation, constantly undermined by the specter of war and the difficulties of subsistence. In Lília Momplé's Neighbours: The Story of a Murder (2012), the hostile actions of apartheid-era South Africa are depicted with the resulting horror they had on urban Mozambique. Similarly, Nelson Saúte's poem "Ruth First," pays homage to the famous South African anti-apartheid activist 
killed by a parcel bomb addressed to her at the Universidade Eduardo Mondlane in Maputo, where she worked in exile. Carlos Cardoso's "Cidade 1985" expresses the heroic survival of Maputo's citizens, portraying the violence of daily life, its power cuts and water shortages in a way replicated in short stories and poems, such as “Anos 80," by Nelson Saúte. In Quem me dera ser onda, Rui captures the maladjustment of people to their new residential space through the combination of a series of absurd daily routines, and simultaneously anticipates the tragic end of the farce. The presence of the war and its consequences also affected the city through the visibility of its most immediate impacts, like disabled war veterans staining the city's fabric, evoked by Patraquim in "Formulação da Avenida": "Sentam-se, sob as acácias, no asfalto roto, / os mutilados com cigarros de embalar. / Nenhum som os recorta / E todos os sentidos foram amputados" (300). Ana Paula Tavares, in "Novembro Without Water" depicts people displaced because of the civil war, such as the street urchins in Luanda: "Olha-me p'ra estas crianças de vidro / cheias de água até às lágrimas / enchendo a cidade de estilhaços / procurando a vida / nos caixotes do lixo" (36).

Today, with peace, a growth of wealth and the embrace of neo-liberalism, these countries and cities have undergone numerous transformations, which their literature is actively recording, thus continuing a path of open political engagement. With a temporarily resident foreign population and an enriched local bourgeoisie, the changes are evident. While there has been a recovery of the cities, mainly in their former colonial zones, there has also been a radical transformation of these spaces, documented by contemporary poets with an intense nostalgia for the Luanda that is disappearing, and an indignation against the conditions under which that transformation has taken place. An example of this occurs in Ana Paula Tavares's poem "As portas de Luuanda" (2005), where machines devour the city, or in the simultaneously outraged and nostalgic poems by Carlos Ferreira, who takes us through the streets of Luanda, through its names, its poets, and the people who fought for freedom only to find nothing. ${ }^{6}$ Another crucial element is the metamorphosis of the cities' outskirts, some into luxury neighborhoods, others into new shantytowns due to the expulsion of the

\footnotetext{
${ }^{6}$ See, for example, his "Ao Mário António," "Na curva do Bairro Operário," "Eu do Makuluso me confesso," and "Ao Viriato da Cruz" among others from Causas Perdidas.
} 
population from the former shantytowns, now in the middle of the city, on terrain coveted for new neighborhoods based on an urban model of major social segregation. These are materializing in gated communities, isolated in all senses from the rest of the city, so well illustrated by Pepetela in O Desejo de Kianda and in the poetry of João Melo, Aires de Almeida Santos, or José Luis Mendonça.

Like the dividing line between the colonial city and the shantytown drawn by Luandino Vieira in the earlier imaginary of these literatures, demarcating the European space from the African space, the new dividing line of the current cities is still based on the same stamp of power and inequality, albeit expressed in an alternative form. And perhaps, in another hangover from the colonial past, the most effective place from which to denounce this inequality remains literature, depicting the interplay between the archaic and the modern, between poverty and the extravagance of the nouveau riche, between exploitation and the easy display of wealth portrayed by Pepetela in Predadores, Luandino Vieira in O Livro dos Guerrilheiros, and Ondjaki in Os Transparentes, as well as in Carlos Ferreira's poetry. In contemporary fiction, there are still many invisible cities, which form and reform the historic and polyphonic cities under permanent mutation.

The cities' most culturally decolonizing and politically revolutionary moment is probably in the literary projects of the Angolans Pepetela and Luandino Vieira, when they go back to the historic texts of António Oliveira Cadornega. As we have seen, the História Geral das Guerras Angolanas contains one of the first descriptions of Luanda as well as poems about the city. In $A$ Gloriosa Família, set during the seventeenth-century Dutch occupation of Luanda, Pepetela recuperates Cadornega's text, rewriting it in order to identify a city and a territory, as well as a people fighting for it. Luandino Vieira does something similar when he purposefully paraphrases Cardonega in his $O$ Livro dos Rios in order to identify a territory and a people suffering but valiantly struggling, from that early moment, to be Angolans, thus assuming a common written literary heritage with the then-colonizer, but one that will become wholly Angolan. The process of taking on this inheritance implies selection, rearrangement, and writing in difference. Through intertextuality, it re-interrogates the original text with which it dialogues, bringing it up to date in a different context and through a different hue of Portuguese. Moreover, A Gloriosa Familia's narrator is a slave, bringing into focus the Other side of history through the voice of those who had experienced it. Ironically, this slave, who is the 
property of Baltazar van Dum, the novel's protagonist, is mute and illiterate. As such, he does not have at his disposal the instruments required to tell his story. Yet precisely through this ontological silence, the subaltern's history emerges. In other words, the Other does have a story to tell, and s/he is quite capable of telling it. It is just that the conditions of production and pronouncement they long endured have led them to an apparent silence. Through his novel, Pepetela writes Luanda from a different spatial and human geography, pronounced in the linguistic expression of an Other, hitherto excluded from History's grand narrative. Through an "unfaithful copy," the multiple legacies that define Angola and, more specifically, Luanda come into play.

The movement of rewriting is a political movement of conquering the territory and its history by narrating versions of history told from other voices and other places, making the history of the city from its beginning textually more polyphonic. This is a movement against the inequality of power to narrate history, a movement of Angolanness, or Mozambicanness. These are forms of re-foundation and citizenship formation, and therefore of a struggle against inequality. They also reflect cities as spaces wide open to life and full of the possibilities of citizenship-in-difference.

\section{Works Cited}

Cadornega, António Oliveira. História Geral das Guerras Angolanas. 1680. Ed. José Mattias Delgado and Manuel Alves da Cunha. Lisbon: Agência Geral das Colónias, 1940-42. Print

Cahen, Michel, ed. "Vilas et Cidades": Bourgs et Villes en Afrique Lusophone. Paris: Harmattan, 1989. Print.

Candido, Antonio. Formação da literatura brasileira: momentos decisivos. Vol. 1. Belo Horizonte: Itatiaia, 1981. Print.

Canevacci, Massimo. A Cidade Polifónica: ensaio sobre a antropologia da comunicação urbana. Trans. Cecília Prata. São Paulo: Nobel, 2004. Print.

Cardoso, Carlos. "Primeiro Aniversário." Antologia da nova poesia moçambicana. Ed. Fátima Mendonça and Nelson Saúte. Maputo: Associação dos Escritores Moçambicanos, 1988. 57. Print.

Couto, Mia. Cronicando. Lisbon: Caminho, 1991. Print. 
"Descrição da cidade de Loanda e reyno de Angola." 1680. Entre a lua, o caos e o silêncio: a flor (antologia da poesia angolana). Ed. Irene Guerra Marques and Carlos Ferreira. Luanda: Mayamba, 2011. 466. Print.

Dias, João Pedro Grabato. Uma meditação 21 laurentinas e dois fabulírios falhados. Lourenço Marques: Dias, 1971. 48-49. Print.

Domingos, Nuno and Elsa Peralta. Cidade e Império: Dinâmicas Coloniais e Reconfigurações Pós-coloniais. Lisbon: Edições 70, 2013. Print.

Faife, Hélder. Contos de fuga. Maputo: A2 Design, 2010. Print.

Ferreira, Carlos M. Causas Perdidas (trinta anos de poesia) 1979-2009. Luanda: União dos Escritores Angolanos, 2011. Print.

Henriques, Isabel Castro and Miguel Pais Vieira. "Cidades em Angola: construções coloniais e reinvenções africanas." Cidade e Império: Dinâmicas Coloniais e Reconfigurações Pós-coloniais. Ed. Nuno Domingos and Elsa Peralta. Lisbon: Edições 70, 2013. 7-58. Print.

Knopfli, Rui. "Winds of Change." Memória consentida: 20 anos de poesia: 1959/1979. Lisbon: Imprensa Nacional-Casa da Moeda, 1982. 152. Print.

Knopfli, Rui. O monhé das cobras. Lisbon: Caminho, 1997. Print.

Lopo, Júlio de Castro. Alguns aspectos dos musseques de Luanda. Luanda: Editorial Angola, 1948. Print.

Noa, Francisco. Império, mito e miopia-Moçambique como uma invenção literária. Lisbon: Caminho, 2003. Print.

Patraquim, Luís Carlos. "Formulação da Avenida." Antologia da nova poesia moçambicana. Ed. Fátima Mendonça and Nelson Saúte. Maputo: Associação dos Escritores Moçambicanos, 1988. 300. Print.

Rossa, Walter. "Stone Raft, Allegory on the Spread of European Urbanistics in Early Modern Times." Joelho 6 (2015): 78-93. Print.

Sousa, Noémia de. Sangue Negro. Maputo: Associação dos Escritores Moçambicanos, 2001. Print.

Tavares, Ana Paula. "As portas de Luuanda." Portuguese Literary \& Cultural Studies 15/16 (2005-06): 37-39. Print.

-. O lago da lua. Lisbon: Caminho, 1999. Print.

Topa, Francisco. "Entre a terra de gente oprimida e a terra de gente tostada: Luís Félix da Cruz e o primeiro poema angolano." Literatura em Debate. Programa de Pós-Graduação em Letras da U. Regional Integrada do Alto Uruguai e das Missões. Rio Grande do Sul. 7:13(2013): 122-47. Print. 
Trigo, Salvato. "Literaturas africanas de expressão portuguesa-um fenómeno de urbanismo." Ensaios de Literatura Comparada Afro-Luso-Brasileira. Lisbon: Vega, 1986. 53-60. Print. 